The Professional Service Firm (PSF) in a globalised economy: a study of the efficiency of securities firms in an emerging market

Mehmet Demirbag*, Martina McGuinness, Ahmet Akin, Nizamettin Bayyurt \& Eyup Basti

Mehmet Demirbag, University of Essex, Essex Business School, Southend-on-Sea, SS1

1LW (E-mail: mdemirc@essex.ac.uk)

Martina McGuinness, University of Sheffield Management School, Sheffield, S1 4DT (E-mail: m.mcguinness@ @ sheffield.ac.uk)

Ahmet Akin, Fatih University, Department of Banking and Finance, 34500 Buyukcekmece, Istanbul, Turkey (Email: akin@fatih.edu.tr).

Nizamettin Bayyurt, Fatih University, Department of Management, 34500 Buyukcekmece, Istanbul, Turkey (Email: bayyurt@ fatih.edu.tr).

Eyup Basti, Fatih University, Department of Banking and Finance, 34500 Buyukcekmece, Istanbul, Turkey (Email: ebasti@fatih.edu.tr).

*= Corresponding author

Professor Mehmet Demirbag

Chair in International Business

University of Essex, Essex Business School

EImer Approach

Southend-on-Sea

SS1 1LW

Tel: +44 (0)1702328200

E-mail:mdemirc@essex.ac.uk 
The Professional Service Firm (PSF) in a globalised economy: a study of the efficiency of securities firms in an emerging market

\begin{abstract}
This study explores the efficiency of securities firms in Turkey and offers conceptual and managerial insights utilizing data envelopment analysis. Through a sample of local and foreign owned securities firms in Turkey, we examine the impact of liabilities of foreignness (LOF) and localness (LOL) upon knowledge intensive firm efficiency in an emerging market economy. We have extended this approach through our consideration of liability associated with market globalness (LOMG). Our findings indicate the importance of size for firm efficiency with bank affiliation and foreign ownership also having positive effects on efficiency. Our study makes a contribution conceptually, methodologically and empirically to a growing literature on emerging economies. We also make a valuable addition to the limited empirical work conducted on the securities industry to date. Finally, through our contextualization of Turkish securities firms as professional services firms (PSFs), our research extends the narrow focus on law and accounting which currently dominates the burgeoning research strand on PSFs.
\end{abstract}

Key words: Performance, securities firms, firm ownership, affiliation, size, liability of foreignness, ownership, data envelopment analysis (DEA), Professional Services Firm (PSF) 


\section{The Professional Service Firm (PSF) in a globalised economy: a study of the efficiency of securities firms in an emerging market}

\section{Introduction}

Capital markets are globally integrated networks of institutional actors spanning national and supra-national strata. In order to be successful in these financial markets, firms must possess knowledge, assets and capabilities which span both local and global institutional dimensions. From a multinational enterprise (MNE) perspective, this necessitates effective knowledge transfer from the foreign parent to the subsidiary; by providing access to technological learning and insights into supra-national institutional norms, the parent reduces uncertainty regarding global imperatives and thereby reduces transaction costs for the subsidiary. Similarly, the transfer of local insights, garnered through the activities of the subsidiary, lessens host country uncertainty for the MNE thereby enhancing transaction cost efficiencies for the parent. Conversely, independent domestic operations, which may benefit from efficiencies at the local level resulting from their market embeddedness, face challenges in managing transaction costs associated with deficiencies in knowledge pertaining to global market institutions. Our research explores these complex institutional relations in terms of the role of 'local market' capabilities, that is, those resources which facilitate effective operations across the national, or meso-level, institutional domain, as well as 'global market' capabilities, that is those resources which facilitate effective operations at the supra-national, or meta-level, institutional domain. We draw upon institutional theory to inform our analysis of these relationships in the context of an emerging economy, Turkey. Moreover, our approach reflects the recognition that institutions are the frame of reference within which firm transactions take place (North, 1990), an approach which is well-established in international business research (Henisz, 2000, Henisz and Swaminathan, 2008, Demirbag et al., 2010a, Wood and Demirbag, 2012; Meyer and Peng, 2016). Through an integration of 
institutional and transaction costs perspectives, our study investigates the relationship between firm level attributes (ownership, affiliation and size) and institutional dimensions (political constraints) and organisational efficiency. We test these relationships empirically using a sample of Turkish securities firms.

Our research makes a contribution to the existing literature empirically and conceptually. The choice of Turkey, positioned as it is between the developed West and developing East provides a unique institutional environment for exploring an industry (the securities industry) operating in an emerging economy at the periphery of Europe. Interest in Turkey is also growing given the ongoing negotiations regarding its potential accession to the European Union (EU). Whilst the Turkish banking sector has attracted interest from scholars (Zaim, 1995, Isik and Hassan, 2002, Isik and Hassan, 2003b, Isik and Hassan, 2003a, Demir et al., 2005, Ihsan, 2007, Isik, 2008, Aysan and Ceyhan, 2008, Fukuyama and Matousek, 2011), there has been comparatively little investigation of its securities industry (Aktas and Kargin, 2007, Bayyurt and Akın, 2014). Thus, in the first instance, we make an empirical contribution through our use of a sample of Turkish securities firms. The selection of Turkish securities firms is novel, and significant, in allowing us to examine efficiency of an industry operating in an emerging market economy, which is at the same time embedded within an advanced global financial sector. In this context, we also build upon work by others on the concept of liability of outsidership (LOO) (Johanson and Vahlne, 2009, Vahlne et al., 2012) through our argument regarding a liability of market globalness (LOMG). Moreover, as securities firms offer professionally based services, we contribute to an emerging body of literature on professional service firms (PSFs), a literature which has been criticised for the its predominant focus upon law and accounting firms (Von Nordenflycht, 2010). We add to this research strand by, firstly, extending this narrow focus to securities firms and, secondly, 
exploring PSF efficiency. The Turkish securities industry offers a unique testing ground for a critical examination of the significance of institutional relationships for firm efficiency across a multi-dimensional network. Methodologically, this paper also offers novelty in approach by utilizing data envelopment analysis (DEA) to evaluate the relative efficiency of securities firms. Whilst there has been extensive use of DEA in operational research or management science field, and some application to the banking sector (see, for example, Wang et al., 2014, Fukuyama and Matousek, 2011, Seiford and Zhu, 1999) and securities (Fukuyama and Weber, 1999, Zhang et al., 2006), there appears to be relatively less adoption of this technique in broader management fields (Demirbag et al., 2010b). This methodology allows us to explore the interplay of institutional and transaction cost issues by utilising key variables of affiliation, ownership and size in conjunction with firm efficiency.

The structure of the rest of the paper is as follows. We present the context for the study, that is the macro-level institutional (Turkish Capital Markets) and the micro-level organisational (securities firms) domains before developing our conceptual model and related hypotheses. Then, we outline the study context and methodology and set out our findings and analysis. We conclude with a discussion of the significance of these findings and their implications for managers.

\section{Background and hypotheses development}

Institutional context for the study: Turkish Capital Markets

Developments in the Turkish securities are best understood in context of the globalisation of financial markets. Institutional actors at both the national (government policy of liberalization) and the supra-national level (e.g. the European Union (EU), the International 
Monetary Fund (IMF) and the Bretton Woods Institutions (BWIs)) have been key influences as Turkey moved from a state managed model of import-substitution industrialisation strategy through the 1960 s and 70 s, to the opening up of the Turkish economy from 1980 onwards (Önis and Bakır, 2007, Sönmez, 2011, Rodrik, 1990, Akyüz and Boratav, 2003). To illustrate, between 1981and 1996, 31 new commercial banks entered the Turkish banking sector accounting for half of the market (of which 18 were foreign owned), compared to 3 new entrants, 1962-80 (Isik, 2008). These new entrants focussed largely upon trade and corporate finance activities (Isik and Hassan, 2003b). There is evidence that the banking sector became more efficient in the wake of the market liberalisation (Zaim, 1995, Isik and Hassan, 2002, Isik and Hassan, 2003b), however it has also been argued that efficiency improvements were not consistent over time (Denizer et al., 2007). The economic transition has not been without problems (Rodrik, 1990, Sönmez, 2011), neither has the pace or focus of change been steady. It is possible to discern particular phases in Turkish market reform: 'de-regulation' (1980-89), 'rhetorical transition and institutional crisis' (1989-2001) and, 'reregulation' (2001 onwards)(Önis and Bakır, 2007).

It is possible to trace the creation of national institutional infrastructure starting in the early 1980s with innovations such as the Capital Markets Act (1981) and the establishment of the Capital Markets Board of Turkey (CMB) in 1982 which paved the way for the founding of the Istanbul Stock Exchange (ISE) in late 1985. In 1989, the decision was taken to completely open up capital accounts with the reactivation of the Customs Union (CU) with the EU following in 1995. These actions were watersheds in throwing open the Turkish economy to the opportunities, and threats, presented by modern global markets (Önis and Bakır, 2007). By October 2009, the market value of the ISE was more than $\$ 200 \mathrm{bn}$ with average daily trading volume of $\$ 1.2 \mathrm{bn}$ (Yorgancioglu, 2010). However, governmental 
perceptions of ISE under-performance led to new leadership and institutional structures in 2012. On 30 December 2012, Capital Markets Board Law no.6362 brought together all Turkish capital markets exchanges into a single securities exchange, Borsa Istanbul with the aim of providing a platform for growth and expansion (Dombey and Boulton, 2013), from which it can then be taken public by the end of 2015 (Dombey, 2013). In Turkey, securities is still an emerging industry. Whilst Istanbul rose from 57 to 44 in the Global Financial Centers Index in 2013 (Turhan, 2014), its Chief Executive has highlighted that Turkey's capital markets performance do not match the country's performance in world trade or its global gross domestic product, and his ambition is to achieve $\$ 1$ tn market capitalisation in the future. (Dombey, 2013)

Reflecting the network nature of cross-border relationships endemic in the post-industrial world economy, Borsa Istanbul owns stakes in the Kyrgyz, Montenegro, Baku and Sarajevo Stock Exchanges. It also has a range of international links which place it solidly within a global finance institutional network through Memoranda of Understanding with Japan Exchange Group, Tirana Stock Exchange, Karachi Stock Exchange and the International Islamic Financial Market. It is also a board member of the World Federation of Exchanges (WFE) and has forged a strategic partnership with NASDAQ OMX, a global technology leader for the finance sector. All of these initiatives are aimed at helping Borsa Istanbul to become "a world-class in-house exchange technology which enables, among other things, linkages with other markets. This vision will add value to the drive of making Istanbul an international financial center.” (Borsa Istanbul, 2013)

Clearly then, the emergence of Turkish securities sector is best understood within a model of punctuated equilibrium. Institutional drivers have been both proactively planned, such as the 
liberalisation of Turkish economic markets in the late 20th century, but also subject to regulatory shifts in response to disruptions resulting from global financial crises (2000-01). The second global financial crisis of the $21^{\text {st }}$ century (2008) resulted in a significant drop of 8\% in GDP in the first three-quarters of 2009 as well as steep rises in unemployment and government deficit (Yorgancioglu, 2010). However, the impacts of the crisis on the Turkish banking sector were mitigated by the institutional reforms instigated by government in the wake of the previous global financial disruption. This meant that whilst export activities and capital inflows fell significantly, financial impacts on the banking sector were less severe relative to other emerging and developed economies (Assaf et al., 2013).

\section{Micro- level context for the study: Securities firms}

Securities firms act as facilitators for the trading of financial instruments. They can carry out a range of different activities, including underwriting new securities, making markets for seasoned securities, and providing services to customers in their financing and investment activities (Liu, 2008). Securities firms are professional service firms (PSFs) in that they are firms where "exceptional and valuable expertise dominates commonplace knowledge" (Starbuck, 1992). and, following the conceptualisation offered by a range of writers (von Nordenflycht, 2010, Greenwood et al., 2007, Sharma, 1997), one in which services are delivered by professionals (Lowendahl, 2000:18). They embody the fundamental characteristics of the PSF: a professionalized workforce and a dependence upon a substantial body of complex information (von Nordenflycht, 2010); low capital intensity, particularly in terms of specialised plant (Teece, 2003, von Nordenflycht, 2010); a work force comprising of 'sophisticated users of information' who possess quantitatively and qualitatively greater knowledge of their chosen areas (Benner, 2010); specialised expertise gained through training 
or experience (Starbuck, 1992, Greenwood and Lachman, 1996), high recruitment and retentions costs (Teece, 2003) and; a lack of knowledge depreciation (Boone et al., 2008). It has been argued that forces of globalisation mean that PSFs are obliged to follow international clients into markets (Greenwood and Lachman, 1996). We argue that this also segues with Johanson and Vahlne's (2009) network perspective on internationalisation and that this is an appropriate perspective to adopt for the highly globalised financial services sector, of which securities firms form a part. In a similar vein, Nachum and Zaheer (2005) found that motivations for FDI in knowledge-intensive industries, such as those occupied by PSFs, were the pursuit of highly paid expert human capital as well as efficiency. For these reasons, PSFs can be found in markets of which they have no experience and limited knowledge, presenting the potential for additional transactions costs arising from doing business in an unfamiliar institutional domain (Zaheer, 1995, Johanson and Vahlne, 2009).

To date, research on securities firms has emerged from a variety of perspectives, such as, industry structure (Johnston and Madura, 2000), regulation (Liu, 2008, Chen et al., 2005), ownership (Chen et al., 2005, Liao and Yang, 2010, Song et al., 2012), technology (Zhang et al., 2006, Williams, 2009), conflicts of interest (Song et al., 2012) and earnings forecasts (Bartholdy and Feng, 2013). There has been some exploration of efficiency and this has largely focused on scope and scale (Goldberg et al., 1991, Hu and Fang, 2010, Lee et al., 2014). We add to this work by developing an integrative model to examine the relationship between the micro-level organisational efficiency of securities firms and their size, ownership (foreign or domestic) and, affiliation (to a foreign or domestic bank). In doing this, we provide insights into the impact of institutional relationships upon the key dimension of security firms' efficiency. The role of stock markets and banks for economic growth is wellrecognised (Levine and Zervos, 1998) and the efficiency of securities firms is of significance 
in this context, not least because, there is evidence to suggest that as economies grow the importance of securities markets increases whilst that of banking declines (Demirguc-Kunt et al., 2011). Furthermore, the inclusion of efficiency (of financial agents and markets in facilitating and broking financial transactions) as one of the key measures underpinning the World Bank benchmarking of global financial systems (Global Financial Development Database) is an powerful indicator of the importance of this variable (Cihak et al., 2012). Securities firms engage in a range of financially based activities: underwriting new securities, making markets for established securities and services in financing and investment activities. More diversified firms may also provide asset management services involving trust funds and derivatives (Liu, 2008). In institutional terms, securities firms, and those analysts employed within them, are "institutional agents ... definers, interpreters and appliers of institutional elements" (Scott, 2008b:29). The activities undertaken by these agents can reduce the costs of transactions through the application of this institutional knowledge i.e. enhance efficiency or, through a lack of institutional knowledge, increase transaction costs, i.e. decrease efficiency.

\section{Institutional specific influences:}

The influence of institutions is seen economically (North, 1990) and organisationally (Scott, 2008a) in international business. It has impact upon the ownership, location and internalisation (OLI) choices made by MNEs (Dunning and Lundan, 2008). This is not least because "specific institutional constraints dictate the margins at which organizations operate and hence make intelligible the interplay between the rules of the game and the behaviour of the actors." (North, 1990:110). Furthermore, organisational forms and practices reflect the influence of normative, regulative and cognitive pillars of institutions (Scott, 2008a). Institutional environment plays a significant role in MNEs' mode decision (Delios and Henisz, 2003a) and subsequent operational and financial performance (Demirbag et al., 
2007b; 2010b). However, uncertainty about the institutional environment reduces the predictability of organisational performance (Werner et al., 1996, Miller, 1992, Miller, 1993) whilst stable, strong institutions reduce environmental uncertainty and reduce transaction costs by, for example, requiring less effort in understanding the policy environment (Delios and Henisz, 2003b). The likelihood of political hazards, unpredicted regulatory changes (de facto or lack thereof), implementation of existing rules, and government interference, are all considered to be important dimensions of the institutional environment in a host country (Henisz, 2000; Demirbag et al., 2009; 2010c; Demirbag, McGuinness, Wood and Bayyurt 2015) and present a 'distance' to be bridged by foreign firms.

Institutional distance between home and host countries can impact in many different ways. Studies have explored the phenomenon of 'foreignness' in terms of its scope and scale (Sethi and Guisinger, 2002, Sethi and Judge, 2009, Nachum, 2010), measurement (Hennart et al., 2002), impact on entry strategies (Chen, 2006, Chen et al., 2006), as well as how firms seek to mitigate its impact (Elango, 2009, Luo et al., 2002, Petersen and Pedersen, 2002). Costs can arise as a result of the environment: costs resulting from the home country (e.g. possible restriction of sales to certain countries) as well as the host country (e.g. economic nationalism); spatial distance (e.g. co-ordination costs) and; firm specific costs emanating from a lack of familiarity with the local environment (Zaheer, 1995). The concept of 'liability of foreignness' (LOF) refers to those costs which stem from institutions, that is the regulative, normative and cultural-cognitive elements of the local domain (Scott, 2008a), and the juxtaposition of the foreign firm with these aspects (Zaheer, 2002). From a financial services perspective, distance can impact upon the availability of relevant information to market participants thereby creating information bias and the potential for efficiency gains from local 
knowledge such as "the accounting practices, the corporate culture, the political events, the current business conditions, to being able to foresee the feeling of exuberance following a victory in a football World Cup Championship" (Portes et al., 2001:786).

However, domestic firms also face challenges, and specifically, a 'liability of localness'. (LOL) (Perez-Batres and Eden, 2008, Perez-Batres, 2012, Jiang and Stening, 2013). The LOL concept offers a converse standpoint, to LOF, on the impact of uncertainty created by institutional distance. Perez-Batres and Eden (2008) argue that, in emerging markets, firms have to cope with sudden shifts in their regulatory environment which necessitate the firm to re-align itself appropriately, thereby creating accompanying additional transaction costs for the business. More recently, other scholars have argued that LOL extends beyond the impacts of punctuated institutional changes with domestic firms finding themselves subject to additional costs from ongoing LOL as they struggle to adapt in the longer term and find themselves perceived to be less legitimate than their foreign owned competitors (Jiang and Stening, 2013). Whilst LOF and LOL integrate institutional and transaction costs in a dyadic manner, the notion of 'liability of outsidership' (LOO) moves towards a multi-dimensional or network perspective for characterising the interplay between institutions and their potential for additional costs arising from accompanying uncertainty (Johanson and Vahlne, 2009, Vahlne et al., 2012). In describing LOO, the authors stress that "outsidership does not necessarily refer to countries. It is a firm-level concept that may relate to a network within a country, or to a wider region" (2009:1421). We develop this idea further and argue that global markets create their own particular firm level liability related to a lack of familiarity with a supra-national institutional domain; a 'liability of market globalness' (LOMG). We define LOMG as the influence of multi-level governance networks in globalised markets and the related potential negative impact upon firm performance arising from the absence of 
appropriate knowledge, information flows and learning capacity spanning local, foreign and global dimensions. This means that some not only MNEs face the challenge of 'multiple embeddedness' across heterogeneous contexts (MNE multiple host locations and host subsidiary levels) (Meyer et al., 2011), so too, MNEs operating in globally integrated markets, such as finance, face the challenge of being appropriately embedded in supranational institutional networks.

This is important because the nature of the institutional domain has the potential to impact negatively upon knowledge management processes, and therefore impact upon efficiency, through, for example, the regulation of capital markets themselves (Bell et al., 2010). Changes in regulation can impact upon ownership structures for securities firms in terms of the potential for foreign ownership and bank affiliation, as well as the scope and scale of securities activities permitted (Whalen, 1999). Organisational structures such as foreign ownership and bank affiliation can facilitate knowledge transfer in securities firms, reducing environmental uncertainty and prompting optimal interactions between the firm and its institutional domain, thereby enhancing transaction cost efficiencies. In this way additional costs associated with LOF are reduced. One manifestation of this can be seen in terms of the substantive information flows about traded assets which underpin the operation of securities firms. This requirement is reflected in peer-to-peer information flows with a concomitant need for effective internal lateral communication (Teece, 2003). Institutional variables such as changes in regulation can reduce information asymmetry and may therefore alter industry structure by reducing the power of expert knowledge (Choi et al., 2009). For example, in the case of Turkish markets, reforms in the wake of the 2000-01 financial crisis increased greater transparency of financial reporting (Assaf et al., 2013). From a LOL perspective, regulatory 
punctuations in the home environment of an emerging market can create additional transaction costs for domestic firms (Perez-Batres and Eden, 2008).

Information asymmetry in financial markets has been explored in terms of the imbalance in knowledge between the expert, i.e. the financial analyst and the client, as well as between experts. In the case of the latter, distance has been identified as a proxy for 'informational frictions' in the trading of information intensive assets such as corporate bonds, equities and treasury bonds, leading to a strong negative relationship between asset trade and distance (Portes et al., 2001). Information asymmetry may also reflect differing levels of institutional development, for example, the United States has higher standards of information disclosure than less institutionally mature countries leading researchers to examine this as source of home bias (Chan et al., 2005, Karolyi and Stulz, 2003). Information asymmetry leads to knowledge which is more readily available to home based organisations and which represents local capabilities which are not necessarily available to foreign competitors. Key factors may impact upon the organisation's ability to firstly, obtain knowledge and then, secondly, to translate this into competitive advantage. Knowledge can be gained first hand, or vicariously. Through relationships with other organisations, the organisation can access knowledge sets built over time by others. Larger firms may be able to integrate these knowledge sets more efficiently and avail from economies of scale in their implementation. However, the nature of the organisation itself in terms of ownership and associated path-dependencies can influence the firm's awareness of, and ability to, transform these knowledge sets. We shall explore these issues more fully by considering the variables of firm affiliation, ownership and size in more detail and relating these to efficiency gains. 


\section{Firm affiliation}

A firm's affiliations have been found to have a significant influence upon performance in emerging economies, and in particular, business group affiliation can influence the survival of a foreign subsidiary (Garg and Delios, 2007). However, learning effectiveness is more important than learning efficiency in a network of international business affiliates (PérezNordtvedt et al., 2010). Affiliation ties can lead to perceptions of organisational legitimacy which, in turn, can contribute to a firm's success. The right interactions with important institutional actors and accommodations to institutional imperatives can be powerful weapons in communicating legitimacy to stakeholders. Mechanisms such as certifications and endorsements (Bell et al., 2010, Christmann and Taylor, 2006) and bonding (von Nordenflycht, 2010) can provide signals of quality to important stakeholders. These forms of institutional interactions can build over time impacting upon the perception of the firm's legitimacy. Thus, legitimacy is seen to increase as the foreign organisation learns and adapts to the host country environment (Zaheer and Mosakowski, 1997). Accordingly, one can argue there is a clear link between resource and capability enhancement (within the specific environmental context) and the firm's likely increase in efficiency over time as LOF dissipates alongside a concomitant decrease in associated transaction costs. Strategic affiliation can allow a foreign firm to accumulate resources through, for example, borrowing (Hamel and Prahalad, 1993) and in this way move through a process of capability building and signalling more quickly. Brand and reputation have been argued to be powerful organisational assets for the PSF (Greenwood et al., 2005). This arises from the limited efficacy of marketing approaches such as advertising, but also due to the bespoke nature of the services provided to clients (Teece, 2003). Affiliation to a recognised 'brand' in the form of an established financial institution allows the securities firm to appropriate this resource. This brand may be domestic or foreign in origin. Thus, affiliation with a domestic or foreign 
bank may afford certain tangible costs efficiencies, through economies of scope and scale or through lower funding costs, e.g. 'safety-net subsidy (Whalen, 1999) as well as symbolic signalling benefits. At the same time, this may come with certain disbenefits. Meyer and Rowan (1977) highlight the potential for loss in organisational efficiency through decreased internal co-ordination and control in pursuit, and maintenance, of institutional myths.

Securities activities have been found to be of growing importance in the business practices of foreign and domestic banks (Whalen, 1999). Foreign banks are likely to have, by their very nature, certain knowledge and experience of the requirements and practice of global markets, and equally importantly the transgovernmental networks which regulate them (Bach, 2010). The Istanbul Stock Exchange (ISE) is still a relative newcomer to international capital markets and, similarly, those firms which operate on the ISE. In comparison to more established foreign firms with multinational experience within global regulatory structures, independent Turkish securities firms are likely to be at a disadvantage in terms of experience and best practice. Moreover, drawing upon evidence from an emerging market, Jiang and Stening (2013) have argued that foreign firms advantages actually impact negatively upon the degree of the benefits that domestic firms accrue from their localness, in effect creating additional costs for the local firms i.e. exacerbating LOL. Further, empirical data indicate that PSFs exhibit learning curves and their rate of learning accelerates with experience (Boone et al., 2008) which would suggest that native independents are further disadvantaged with respect to their speed of knowledge accumulation relative to their multinational counter-parts. The latter, whilst lacking in local experience, have developed more rapid learning pathways and therefore have greater learning capabilities. 
Acquiring securities firms can offer banks potential benefits such as risk reduction through diversification and efficiencies gained through economies of scale. Further, the enhancement of product range through acquisition can also facilitate sales synergies across securities and banking customers (Johnston and Madura, 2000). The authors also posit that banks benefit from customers' perceptions of banking integrity and thus are more likely to purchase investment services from those affiliated to banks. More broadly, the evidence supporting assumptions of synergies is not consistent (Akhigbe and Madura, 2004). Whalen (1999) found that performance was weak after banks acquired securities firms when compared to performance after the acquisition of other banks. It may be that this finding reflects, in part, challenges posed by organisational fit (Greenwood et al., 1994). Although there is some empirical data, drawn from foreign securities subsidiaries of US Banks, indicating that bank subsidiaries tend to be more efficient, the author acknowledges that this data is not definitive (Whalen, 1999).

From the discussion above, it is credible to suggest that affiliation, to a domestic or foreign bank, may share similar benefits, for example, in terms of signalling. Affiliation to a domestic bank may help a foreign securities firm to cope better with LOF challenges; whilst a domestic securities firm's affiliation to a foreign bank may offer advantage in overcoming LOL to some degree. There is evidence that greater benefits are afforded to foreign affiliates which out-perform local firms but these benefits disappear when compared to local MNEs (Nachum, 2010).

H1. The bank affiliation of a PSF is positively related to organisational efficiency. 


\section{Firm ownership}

Whilst state-owned banks in transition economies have not been found to be significantly less efficient than privately-owned banks (Bonin et al., 2005). Ownership is important to the performance of PSFs with private firms and partnerships found to outperform public corporations (Greenwood et al., 2007). Government ownership has been found to correlate with poor performance in Chinese securities firms (Chen et al., 2005). For privately owned companies, governance structures which reflect foreign or domestic ownership have the potential to impact negatively upon firm performance through LOF or LOL respectively. However, evidence from China indicates that LOL can extend over the longer term, far beyond the short term impacts of a suddenly changing regulatory environment (Jiang and Stening, 2013).

Cultural distance as a source of LOF is well explored but there is not complete agreement on how, and if, this impacts at the level of the firm (Mezias et al., 2002). Kostova and Zaheer (1999) argue that negative perceptions of the legitimacy of foreign owned firms might lead customers to opt to conduct business with local firm and, similarly, labour. At the level of the firm, Zaheer (1995) identifies two methods by which MNEs may seek to counteract LOF. They must either bring firm-specific resources and capabilities to its foreign offshoots to mitigate foreignness, or engage in a process of local isomorphism to such a degree that any advantage host country incumbents might have is neutralised. In other words, foreign firms have to actively enhance efficiencies in order overcome institutional distance and outperform domestic competitors.

However, the degree of institutional distance between home and host can have a material effect on the degree to which foreign owned firms incur additional transaction costs relative 
to their domestic competitors. Subsidiaries owned by foreign companies that have closer ties to the host country are subject to fewer transactions costs arising from socio-political difference (Rangan and Drummond, 2004) are therefore likely to exhibit greater efficiencies than foreign competitors who are more distant from the host country. Market liberalisation and changes in regulation can also go some way to reducing the disadvantages that foreign owned organisations may experience (Nachum, 2003, Nachum, 2010, Perez-Batres and Eden, 2008) and reducing institutionally related transaction costs. However, there are also arguments that domestic firms remain the main beneficiaries of promarket reforms in developing countries (Cuervo-Cazurra and Dau, 2009). Finally, the location choice of foreign-owned subsidiaries can be significant, particularly with respect to 'cosmopolitan' locations. In global cities, the playing field is more level for foreign and domestic firms (Nachum, 2010).

Conversely, foreign ownership may result in enhanced efficiencies for the subsidiary through access to knowledge and information flows not available to domestic firms. From this perspective, domestic firms suffer from LOL due to their lack of knowledge of, and access to, the multi-governance institutional networks prevalent in globalised markets. Such depravation may result in added transaction costs and inefficiencies for the domestic competitor.

H2. Foreign ownership of a PSF is positively related to organisational efficiency.

\section{Firm size}

Firm size can be an important variable in determining the extent to which changes in the institutional landscape impact upon the firm. As an aggregate of the phases of deregulation, a 
case study of Japan showed that smaller firms were disproportionately affected by securities commission deregulation (Liu, 2008). The increased competition which is facilitated through the opening up of markets, drives down commission and may mean that a larger client base becomes increasingly important, as can the degree to which the securities firms engage in commission based activities. Consequently, Liu found that larger firms were significantly less dependent upon commission income than their smaller competitors.

Size can also be affected by technological innovation as technology directly affects the potential for growth of the firm. Whilst ICT facilitates significant increases in transaction volumes (Liu, 2008), within the financial services literature there is a lack of consensus as to whether larger firms are more efficient. As Walter (2009) points out, logic would seem to dictate that that this should be the case given the high fixed costs of this information and transaction intensive industry and the corresponding opportunity for economies of scale. Indeed, examining investment banks in G7 countries Radić et al (2012) found that bank asset size related positively to firm cost and profit efficiency, whilst, from a developing economy perspective, Liao and Yang (2010) also found a positive relationship between size and efficiency in their study of Taiwanese securities firms over a 15 year period (1992-2007). However, there is a counter argument that diseconomies may occur in very large firms as a result of factors such risk and quality (Altunbas et al., 2000). Equally, administrative overheads and the management of complexity can lead to diseconomies of scale. Having said that, the size and global presence of a PSF may be taken as proxies for quality by clients (Lowendahl, 2000) thereby providing additional signals of organisational legitimacy and contributing to a virtuous circle of growth in the client base for a securities firm. Zaheer and Mosakowski (1997) argue that size represents another variable of liability which faces the firm and one which should be considered alongside LOF. In their work on currency trading 
rooms, the authors did not find a correlation between parent size or trading room size on survival but advised caution in interpreting this as significant in itself as they acknowledged there were certain limitations in this aspect of their study.

Other perspectives have suggested that the nature of the heterogenous and customised services provided by the PSF make traditionally based economies of scale problematic to realise within the primary activities of the firm itself. However, transaction cost efficiencies may be achieved through 'upstream' knowledge management. This may be typified by global information systems, globally assigned responsibilities for knowledge gathering, creation and dissemination in specific areas and corporate employee training and development programs (Lowendahl, 2000:154).

H3. The size of a PSF is positively related to organisational efficiency.

\section{Political constraints}

Constraints imposed by formal political and institutional checks and balances limit governmental policy volatility thus providing a more stable environment for investment and growth (Henisz, 2004). Perceptions of higher levels of risk in the institutional domain lead MNEs to make strategic decisions geared towards reduced equity ownership (Miller, 1992, Miller, 1993) and low control modes of entry (Ahmed et al., 2002). However, this may not be the case always, particularly with respect to outward FDI decisions from emerging market MNEs. Evidence from Chinese MNEs has found that political risk was not related to outward FDI location decisions (Buckley et al., 2007, Quer et al., 2011, Cui and Jiang, 2009). Furthermore, perceptions of political risk may not impact in the same way across manufacturing and service sectors. Miller (1993) found that risk perceptions were the same 
across different sectors and higher levels of perceived risk lead service firms to adopt integrated entry modes (wholly owned). (Brouthers et al., 2003). However, there is also some evidence to suggest that service firms are more sensitive to macro-economic risks (e.g. fluctuations in inflation, interest and exchange rates) with key differences between manufacturing and service sectors arising from whether investment is primarily capital or human resource based (Brouthers and Brouthers, 2002, Brouthers and Brouthers, 2003).

Unstable institutions can also impact upon the efficiency of firm operations as a result of policy volatility and the concomitant likelihood of political hazards and unpredictable regulatory changes. Institutional voids can arise from weak institutions which can then be filled by a range of activities, including corruption, which can potentially impact negatively on firms (Rodriguez et al., 2005, Rodriguez et al., 2006, Uhlenbruck et al., 2006). A lack of transparency means that costs are harder for firms to estimate (Calhoun, 2002, Doh et al., 2003), promoting transaction cost inefficiencies. Inadequacies in the rule of law and the enforcement of contracts mitigate against secure property rights creating further unpredictability in the business environment.

H4. The level of democracy in a host country is positively related to organisational efficiency of a PSF.

\section{Moderating effects}

As outlined earlier, in the study context, securities firms in Turkey have faced a turbulent and rapidly changing regulatory environment and the concomitant challenges of aligning themselves to a punctuated institutional equilibrium. Economic and financial reforms were a key response to the impacts of the global 2000-01 financial crisis felt in Turkey and signalled a move towards a risk based regulatory approach more broadly aligned with international standards such EU directives and Basel II (De Jonghe et al., 2012). 
H5. The financial crisis moderates the relationship between the ownership of a PSF (foreign and domestic) and its organisational efficiency.

H6. The financial crisis moderates the relationship between a PSF's bank affiliation and organisational efficiency.

H7. Foreign ownership of a PSF moderates the relationship between a PSF's bank affiliation and organisational efficiency.

H8. The size of a PSF moderates the relationship between a PSF's bank affiliation and organisational efficiency

Our conceptual framework (figure 1.) captures these variables and also illustrates the moderating effects of firm and global level variables.

\section{[Insert Figure 1 here]}

\section{Methodology}

The earliest securities firms started to offer financial intermediary services in Turkey following the start of ISE operations. Regulations allowed securities firms to offer a range of services: intermediary security issues and security trades, transacting of repos and reverses, investment consultancy and portfolio management services, however, separate licences from the $\mathrm{CMB}$ are required for each activity. In the ISE, banks were allowed to provide the same services as those offered by securities firms. From 1997, the CMB mandated banks to establish separate securities firms for stock market services. This resulted in establishment of new securities firms affiliated to the banks. Table 1 depicts the number of independent and bank affiliated securities firms operating in Turkey. By the end of 2000, there were a total of 
123 securities firms operating in the ISE. Of these, 74 were independent and 49 affiliated to banks. However, these numbers had reduced to 62 and 25 respectively until the end of 2011.

\section{[Insert Table 1 here]}

The growth in size of the Turkish securities industry from 2005-11 can be seen in Table 2 . Total securities firm assets increased by $128 \%$ over this period with concomitant net commission revenues growing by $18 \%$ and net income growing by $25 \%$. In $2011,60 \%$ of the securities sector's aggregate revenue came from commission, $21 \%$ corporate finance and asset management activities, $14 \%$ from other revenues mainly including interest incomes and dividend revenues and 5\% from security trades (Association of Capital Market Intermediary Institutions of Turkey).

\section{[Insert Table 2 here]}

\section{Sample Characteristics}

This study is based upon a data set of securities firms taken from the web site of the Association of Capital Market Intermediary Institutions of Turkey (TSPAKB) ${ }^{1}$. Our data set includes 600 observations from 2005 to 2011 (see Table 4). 426 observations belong to independent and 174 observations belong to bank affiliated securities firms. Breakdown of the observations according to ownership is as follows: 438 domestic private, 138 foreign and 24 domestic public.

\footnotetext{
${ }^{1}$ From this data set, we drop the securities firms with negative output since DEA does not provide reliable results with negative data.
} 
A two stage analysis of the data is carried out. Firstly, Data Envelopment Analysis (DEA) is used to measure the relative performance of the securities firms. DEA is a linear programming based approach for measuring the relative efficiency of organizational units (or in DEA terminology, decision making units, DMUs). Originally proposed by Charnes et al. (1978) and based on Farrell's (1957) seminal work, DEA has received significant attention in recent years due to its many advantages over traditional methods. First, DEA produces a single score for each unit to make the comparison easy among the similar units. It is based on peer group comparison in which efficient units will form the efficiency frontier and inefficient units will be enveloped by this frontier. Unlike ratios, DEA is a powerful aggregate method for assessing the productivity of organizations with multiple incomparable inputs and outputs which can be expressed in different units of measurement. Since a best-practice function is empirically built from observed inputs and outputs, there is no need for any assumption about the form of the production function (Cooper et al., 2000). In contrast to regression methods which state only average relationships between multiple inputs or outputs, but not both, DEA focuses on individual observations and optimizes the performance measure of each unit. A prior knowledge of weights or prices for inputs and outputs as well as the form of functional relationship between them is not required in DEA (Cooper et al., 2000).

DEA analysis is an appropriate technique to examine relative efficiency of securities firms as there are multiple inputs and multiple outputs. In operations research, DEA has long been recognised as a robust methodology appropriate to performance evaluation (Fukuyama and Weber, 1999, Seiford, 1996, Demirbag et al., 2010b, 2007b). DEA has been used for empirical examination of the relative efficiency firms in banking (Drake and Howcroft, 1994), securities (Fukuyama and Weber, 1999, Zhang et al., 2006) and many other industries (Demirbag et al., 2010b). In this paper, we argue that DEA can be adopted to examine the fit 
between the organization's strategy and its environment and performance outcome; hence it is a robust analytic tool for international business/strategy fields. For an overview of the evolution of DEA as an analytical method and its utilisation, together with a bibliography of work between 1978 and 1992 reporting 470 published articles, see Seiford (1996).

Analytic approaches such as regression are parametric; however the main advantage of DEA is that it provides a parameter-free approach. A parametric regression estimates a production function and assesses each firm's performance according to its residuals relative to the fitted parameters economy-wide production function (Lauterbach and Vaninsky, 1999). In contrast, for each analysed firm, DEA constructs a comparable virtual firm consisting of a portfolio of other sample firms. In this way, the relative performance of the firm can be determined. In general terms, the efficiency of a particular unit can be defined as a ratio of the value of outputs to the value of inputs, where maximum efficiencies are restricted to 1 ; thus, the efficiency of a unit must be less than or equal to 1. DEA presents and solves the following linear programming problem for each firm:

$$
\operatorname{Maxh}_{o}=\sum_{r=1}^{S} u_{r} Y_{r o}
$$

subject to

$$
\begin{aligned}
& \sum_{i=1}^{m} v_{i} X_{i o}=1 \\
& \sum_{r=1}^{S} u_{r} Y_{r k}-\sum_{i=1}^{m} v_{i} X_{i k} \leq 0 \\
& u_{r}, v_{i} \geq \varepsilon, \quad k=1, \ldots ., n, \quad r=1, \ldots ., \text { s and } i=1, \ldots, m
\end{aligned}
$$

where $\mathrm{X}_{\mathrm{ij}}$ and $\mathrm{Y}_{\mathrm{rj}}$ stand for the amount of $\mathrm{i}$-th input and $\mathrm{r}$-th output of $\mathrm{j}$-th decision-making unit (DMU), respectively. $v_{i j}$ and $u_{r j}$ are the weights of $i$-th input and $r$-th output when $j$-th DMU is under consideration. $n$ is the number of firms in the sample, $s$ is the number of outputs, and $m$ is the number of inputs that the analyzed firm produces and uses respectively. $\varepsilon$ is a very 
small positive number that ensures that every input and output has a value greater than zero. In this form, the most favorable weight set for $\mathrm{DMU}_{0}$ is chosen, which maximizes the weighted sum of outputs of $\mathrm{DMU}_{0}$. The model is the original formulation represented in Charnes, Cooper \& Rhodes (1978). The model assumes a constant return to scale (CRS). According to CRS, if the inputs of a DMU are doubled, the outputs will also be doubled. In this study, a constant return to scale is assumed. The duality component of this model is an input oriented model since it points out the inefficiencies in the input consumption of $\mathrm{DMU}_{0}$. In the input-oriented models, the DEA method seeks to identify technical inefficiency as a proportional reduction in input usage. Measuring technical inefficiency as a proportional increase in output production is also possible. These two measures provide the same value under CRS.

Variable measurement:

Inputs and outputs for DEA

Organizational efficiency is a multifaceted concept, and the strategic management literature recognizes that it is difficult to select a single measure for a firm's performance. DEA overcomes this difficulty by deriving an index of a firm's efficiency by transforming inputs into outputs relative to its counterparts (Demirbag, et al., 2010b). Although there is no consensus on which inputs and outputs are the most appropriate to calculate the efficiencies of securities firms, Greenley (1994) notes that several quantitative objectives can be set to guide firm performance (output) over a period of time. Shrader et al. (1984) observe that output variables have been measured in numerous ways (sales, profit, return on asset, return on equity, etc.) which should be used to reflect the nature of a firm or industry. For instance, Zhang, Zhang and Luo (2006) determine outputs by considering types of services of securities firms. Thus, their outputs are commission revenue, trading gains resulting from 
market making, investment banking revenue, revenue from asset management, and total revenue. Given the nature of securities firms we decided to use three commonly used dimensions as firms' output. These dimensions are revenue (Zhang et al., 2006, Fukuyama and Weber, 1999, Demirbag et al., 2010b), profitability (Demirbag et al., 2010b, FernandezCastro and Smith, 1994) and sales (Demirbag et al., 2007b; 2010b, Fernandez-Castro and Smith, 1994). This study operationalises commission revenue and other revenues as outputs to reflect the above mentioned dimensions. As far as inputs are concerned, while there is no consensus in number and nature of inputs, Fukuyama and Weber (1999) suggest that securities firms are assumed to use two main groups of inputs; namely capital (physical capital), and labour (human capital). Following Fukuyama and Weber's definition of inputs for securities firms, therefore we use two main inputs: physical capital and labour. We use fixed assets to reflect physical capital and number of employees to reflect human capital. Descriptive statistics about the inputs and outputs are given in Table 3.

\section{[Insert Table 3 here]}

In the second stage, outputs from the DEA in the form of efficiency scores are combined with contingency factors in a panel regression analysis in order to determine the effects. These contingency factors are bank affiliation (affiliated/independent), ownership difference (domestic private/domestic public/ foreign) and size of PSFs (correlation matrix is given in table 6). We also include interaction variables in order to find out the effects of ownership and bank affiliation during the crisis years.

Dependent variable: Dependent variable used in panel regression models is efficiency of firms derived from DEA. 
Independent variables used in the panel regression analyses were measured as following:

Bank affiliated: This is a dichotomous variable, coded 1 if the firm is bank affiliated 0 if the firm is independent. This measure aims to examine the affiliation impact on efficiency of PSFs.

Ownership: Ownership structures of firms were classified into three categories; foreign, domestic private and domestic state. Dummy variables are used for this, domestic private is the base dummy.

Size: PSF size is measured by natural logarithm of assets.

Polcon: The political constraint index (POLCON) developed by Henisz (2000; 2004) measures the feasibility a change in policy given the structure of political instuitions in a nation (Henisz, 2000). The POLCON database covers all major nations and calculated for almost every country in the world for the post war period $(1960-2012)$. The POLCON index represents the degree of existence of checks and balances in an institutional environment therefore it is an important proxy for the longitudinal institutional environment for Turkey. The database has been extensively utilised in the extant literature (Henisz, 2000; Neumayer and Spees, 2005; Demirbag et al, 2007a, 2009; 2010c). Scores range from 0 to 1 ( $1=$ democracy; $0=$ dictatorship), as the value of the index approaches to 0 , an increase in the likelihood of political intervention is expected in a given host country. 
Crisis years: 2008 and 2009 are coded by 1 as crises years and other years are coded by 0 . We employ a dummy variable for the years 2008 and 2009 to detect the effects of financial crisis.

We also examine the interaction effects for: foreign ownership and crisis years, domestic state ownership and crisis years, bank affiliation and crisis years, foreign ownership and bank affiliation bank affiliation and size of PSFs. Thus our panel regression model is specified as following:

Efficiency $_{i t}=\hat{\beta}_{0}+\hat{\beta}_{1}$ Affiliation $_{i t}+\hat{\beta}_{2}$ State $_{i t}+\hat{\beta}_{3}$ Foreign $_{i t}+\hat{\beta}_{4}$ Size $_{i t}+\hat{\beta}_{5}$ Polcon $_{i t}+\hat{\beta}_{6}$ Crisis $_{i t}+$ $\hat{\beta}_{7}$ Foreign $_{i t} x$ Crisis ${ }_{i t}+\hat{\beta}_{8}$ State $_{i t} x$ Crisis ${ }_{i t}+\hat{\beta}_{9}$ Affiliation $_{i t} x_{\text {Crisis }}+\hat{\beta}_{10}$ Foreignx Affiliation $_{i t}+$ $\hat{\beta}_{11}$ Affiliation $_{\text {it }}$ Size $_{\text {it }}$

\section{Analysis and Results}

Table 4 below gives a summary of the results of DEA over 7 years from 2005 to 2011. Bankaffiliated securities firms' efficiency is $16.60 \%$ higher than independent firms' efficiency on average. While bank-affiliated securities firms' mean efficiency score is 0.3485 , independent firms' mean efficiency is 0.1825 . The minimum efficiency score of independent firms is 0.01 , but it is 0.026 for bank-affiliated firms. The mean efficiencies of domestic private firms, domestic public firms and foreign firms are $0.1714,0.2178$ and 0.4212 respectively. Mean efficiencies of securities firms do not change significantly during the study period. The lowest efficiency score is observed as 0.1809 in 2006 and the highest efficiency score is 0.2668 seen in 2011 .

\section{[Insert Table 4 here]}


The initial efficiency scores created through DEA were inputted to a panel regression analysis in order to examine propositions developed in this paper. The three classical panel regression models namely, Fixed effects, Random effects and Pooled regression are employed in the analysis. According to the models in Table 5, which gives the coefficients of the factors of securities firms, all the three models yield similar levels of statistical significance for independent and interaction variables. The Hausman specification test suggests that a fixed-effect model is more appropriate than a random-effects model. Fixed effects, random effects and pooled effects are reported in Table 5.

As the panel regression models presented in Table 5 indicate, the bank affiliation, foreign ownership and size (in assets) have significant impact on PSFs efficiency, providing significant support to $\mathrm{H} 1, \mathrm{H} 2$ and $\mathrm{H} 3$. The regression coefficients indicate that that, on average, foreign firms have higher efficiency than their domestic private counterparts. Similarly bank affiliation positively affects PSFs' efficiency in the Turkish context. As far as size of securities firms are concerned by assets, larger size firms emerge more efficient relative to smaller firms.

Political constraints emerge as an important factor in the efficiency of PSFs. Results presented in Table 5 indicate that, both in fixed effect and random effect models, there is a positive relationship between the level of democracy (as polcon index approaches to 1) and the efficiency of PSFs which provides significant support for $\mathrm{H} 4$.

The results of the moderation analyses shown in Table 5 suggest that other independent variables which are crisis years, domestic state, the interaction of foreign securities and crisis 
years and the interaction of domestic state and crisis years have no significant effects on efficiency of securities firms. Therefore H5 was not supported.

Years of crisis, whilst showing a negative coefficient, did not emerge as statistically significant however, interaction with independent variables indicate an interesting outcome regarding the efficiencies of PSFs. While the interaction of crisis years with foreign ownership mode of PSFs (with both domestic and foreign firms) does not create any significant impact, its interaction with bank affiliated firms created a positive and significant impact. While there is no support for H5, H6 received significant support. The interaction of foreign ownership with bank affiliation however has a negative sign coefficient implying that when foreign ownership coupled with bank affiliation, it creates relatively negative impact on performance of PSFs in the Turkish context. Similarly, the interaction between bank affiliation and the size of firms emerge as a negative interactive impact on the efficiencies of firms in this study. Therefore both $\mathrm{H} 7$ and $\mathrm{H} 8$ do not receive support in the direction that we expected.

\section{[Insert Table 5 here]}

\section{Conclusions and implications}

Our results show that bank affiliation has a positive effect on firm efficiency (Table 5). Bank affiliation raises efficiency by $16 \%$ compared to independent. This may reflect a number of different factors. Firstly, at a cultural level, Kwok \& Tadesse (2006) argue that countries with higher uncertainty avoidance are more likely to have a bank-based system. Historically, banking has been the backbone of the Turkish financial system - the Turkish stock exchange was established only in 1985 and, drawing upon Hofstede's cultural dimensions, Turkish culture has very high levels of uncertainty avoidance. In this context, a significant correlation between bank affiliation and efficiency is not surprising. Our findings regarding bank 
affiliation also supports other work on the importance of signals of legitimacy and security to firm clients which affiliation, particularly with a strong banking brand, can provide to securities firms (Bell et al., 2010, Christmann and Taylor, 2006, von Nordenflycht, 2010, Greenwood et al., 2005). Practically, bank affiliation may also increase efficiency through providing access to knowledge and information on financial market practices (Bach, 2010) thereby enhancing efficiency. However, the effectiveness of this will depend upon the securities firm's absorptive capacity (Cohen and Levinthal, 1990, Eriksson and Chetty, 2003), meaning that the greater the firm's learning capacity, the better its absorptive capacity (Simonin, 2004).

It is interesting to note that this positive relationship between affiliation and efficiency does not appear to hold for large bank affiliated firms. We might speculate that size negatively impacts upon firm efficiency for bank affiliated firms because small firms are more dynamic and flexible. It may be that bank affiliated smaller firms are reliant more upon a smaller client base built upon personal contacts and relationships between these clients and individual professionals. Affiliation to a bank may contribute positively to this dynamic through enhancing perceptions of legitimacy around the professional-client relationship.

We found that the effect of foreign ownership is positive on efficiency but negative for bank affiliated firms. Consequently, our results do not support previous work which suggested that distance acts as a proxy for informational asymmetries, leading to a disadvantaging of foreign firms (Portes et al., 2001, Portes and Rey, 2005). Rather, they suggest that strategic alliances can indeed act as powerful positive influences for organisational absorptive capacity (Flatten et al., 2011). Furthermore, our findings point towards the need for a more nuanced understanding of the nature of knowledge flows and learning capacity within the context of 
globalised financial markets. In other words, institutional distance is not simply dyadic, or indeed strictly linear, it is diffused across a multidimensional network. Turkish securities firms operate in a global industry which requires them to mediate a network of local, national and trans-national institutional imperatives. Consequently, to consider knowledge and information flows from a linear perspective reveals only part of a more complex picture.

Whilst some commentators have argued that in the PSF, size is no guarantee of increased profits (Lowendahl, 2000) and that securities firms experience economies of scale at smaller sizes (Goldberg et al., 1991), our findings strongly indicate a positive relationship between size and efficiency. Our results show that as size increases, efficiency increases but size negatively impacts upon firm efficiency across bank affiliation. Our findings regarding the relative inefficiency of small firms correlates with previous work on small knowledgeintensive businesses services firms which found that they struggled to establish and sustain effective knowledge management practices (Huggins and Weir, 2012).

It is also possible that the small size of firms may be indicative of firms which are younger and therefore lacking in experience relative to larger and foreign owned organisations. As elaborated upon earlier in the paper, the ISE was founded relatively recently and so the firms operating on it are relative neophytes and the industry is concentrated in nature. This is an important consideration given that the possession of knowledge, and the complementary practice of knowing, are mutually reinforcing and enhanced through repetition (Marabelli and Newell, 2014) and, evidence that PSFs' learning curves increase with experience (Boone et al., 2008). 
The acquisition of knowledge through effective information flow is only one component, albeit a significant component, in enhancing firm efficiency. For firms operating in international capital markets, it may be that prior related knowledge of the international domain is just as, or even more, important than locally based knowledge as it allows them to overcome LOGM. At the same time, mechanisms for the effective appropriation of knowledge and the ability to transform this into commercial advantage are vital. Our findings indicate that large firms are more efficient, irrespective of ownership or affiliation. This may reflect that smaller firms have less absorptive capacity (MacPherson and Holt, 2007) or that they are less effective at the iterative aspect of this process which has been found to be particularly important for knowledge intensive firms (Patterson and Ambrosini, 2015).

Our argument regarding LOGM has important implications for managerial practice. If multidirectional flows of knowledge are necessary to effectively function within the multidimensional institutional domain within which securities firms function, then organisations need to explicitly engage in processes to capture these knowledge sets. Previous work has identified the need to establish organizational rules, procedures and structures to embed new knowledge in order to help the stability of IJVs in emerging economies (Fang and Zou, 2010). We argue that knowledge intensive firms providing expert professional services (PSFs) face similar imperatives. However, in the case of securities firms, embedding such approaches at the level of the firm serves different purposes, reflecting these broader institutional drivers. For foreign firms with host country subsidiaries, reverse knowledge transfer allows the appropriation of local resources and capabilities which can help mitigate or circumvent additional transaction costs associated with informational asymmetry (Millar and Choi, 2009) and therefore, LOF. For independents in the host country facing foreign 
competition, there is a need to complement their locally based capabilities with global insights, thereby reducing additional transaction costs associated with LOL.

The nature of the firm's prior knowledge is important as it acts as a foundation for effective absorptive capacity. For smaller domestic firms, this may mean giving consideration of recruiting human capital that has international experience of global capital markets. Whilst this is likely to be a more expensive resource to acquire (Teece, 2003), it may act as an activation trigger (Zahra and George, 2002) allowing individual based knowledge of multilevel governance networks to transfer to the organizational level (Eden, 2009). Arguably this reflects, from a domestic viewpoint, Nachum and Zaheer's (2005) observations on FDI decision making in knowledge-intensive industries. The pursuit of highly paid expert human capital must be within the purview of both domestic and foreign securities firms with thought given to the most appropriate design of the PSF (Teece, 2003). Human capital resource is a critical factor, not simply in mitigating LOL or LOF, but crucially LOMG. This expertise is not simply around securities specific knowledge but, more importantly, knowledge and experience relating to the supra-level institutional environment within which securities related services takes place. This is not least because that experience potentially provides the individual-level friendship ties which have been found to be more effective mechanisms for knowledge flow (Bell and Zaheer, 2007).

Our findings with respect to the positive relationship between bank affiliation and firm efficiency but negative with respect to size in bank affiliated firms indicate that managers need to give careful thought to the profile of their firm. Profile is one of Lowendahl's (2000) 5Ps of PSF performance and comprises persuasiveness and credibility. For smaller firms, where profile is largely focussed upon individual professional-client relationships, the 
concomitant transaction costs of affiliation are not worthwhile and should not be pursued. Knowledgeable clients, confident in their own market insights, are likely to be less concerned by signals of organisational legitimacy. Instead they are attracted to the more personalised service offered by small firms. However for large firms, where these professional-client relationships are likely to be weaker, and the clientele different also in terms of market knowledge, the situation is different. There is strong evidence that forging relationships with banks can confer powerful signals of legitimacy and this is likely to be of benefit for large firms. Furthermore, our findings show that managers in securities firms which are engaging in a growth strategy need to give careful consideration to how best manage the transition from small to large, particularly in terms of shifting the basis of client perceptions of the PSF's credibility and legitimacy. Previously, this issue has been highlighted with respect to diversification strategy only (Greenwood et al., 2005), rather than in terms of growth more generally. Our findings with respect to the years of financial crisis (2008 and 2009) serve to reinforce the need for careful consideration of institutional influences in the impact of affiliation relationships. Our analysis does not show foreign ownership to be an important factor, however, it does demonstrate a significant positive impact of foreign ownership with bank affiliation during these periods of global economic turbulence. Clearly then, critical evaluation between, and across, the interactions of variables is needed, echoing once again, the limitations of an overly simplistic or dyadic approach. This evaluation must also be carried out within the context of an institutional context which may be subject to disruptive change.

In conclusion, our study, based upon a novel sample of Turkish securities firms, has allowed us to provide insights into the efficiency of securities firms operating in an emerging economy within the context of an advanced global financial sector. It has highlighted the 
need for a more nuanced view of the relationship between firm affiliation and efficiency, particularly in light of the profile of the firm, especially with respect to its size. Moreover, as PSFs are becoming increasingly important as their share of GNP and employment continues to grow (Lowendahl, 2000, Teece, 2003, Delong and Nanda, 2003, Sharma, 1997), we make a contribution to an emerging body of literature on professional service firms. Through a sample of Turkish securities firms, we have been able to explore liabilities of foreignness and localness in an emerging market economy. We have extended this approach through our consideration of LOMG. Our results serve to reinforce the significance of Nachum's (2010) call for a better understanding of the grounds for performance differentials between foreign and local firms so that appropriate strategic response can be tailored to different reasons for these differences. Our study makes a contribution conceptually, methodologically and empirically to a growing literature on emerging economies. We also make a valuable addition to the limited empirical work conducted on the securities industry to date. Finally, through our contextualization of Turkish securities firms as professional services firms (PSFs), our research extends the narrow focus on law and accounting which currently dominates a burgeoning research strand on PSFs. 
Figure 1. Conceptual Framework

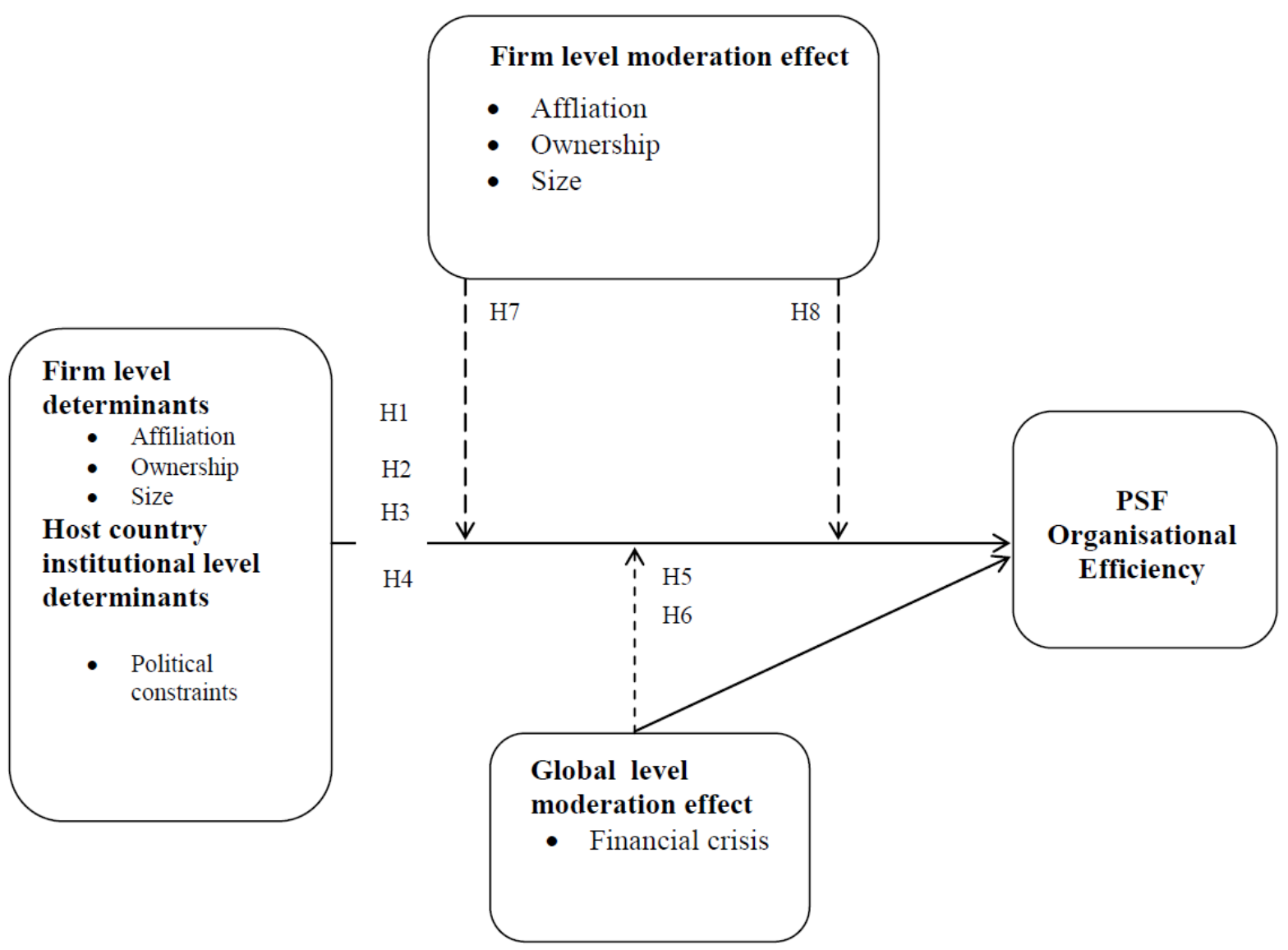


Table 1. Total Number of Securities Firms in Turkey

\begin{tabular}{llllllllll} 
& 2000 & 2005 & 2006 & 2007 & 2008 & 2009 & 2010 & 2011 \\
\hline Independent & 74 & 69 & 70 & 68 & 67 & 60 & 58 & 62 \\
Bank Affiliated & 49 & 32 & 29 & 31 & 31 & 29 & 28 & 25 \\
\hline Total & 123 & 101 & 99 & 99 & 98 & 89 & 86 & 87 \\
\hline Source: The Association & of & Capital & Market & Intermediary & Institutions of & \\
http://www.tspakb.org.tr/index.htm
\end{tabular}


Table 2. Selected Aggregate Data about Turkish Securities Industry (in million \$)

\begin{tabular}{|c|c|c|c|c|c|c|c|c|}
\hline & & & & & & & & Change \\
\hline & 2005 & 2006 & 2007 & 2008 & 2009 & 2010 & 2011 & $\begin{array}{l}\text { from } 2005 \\
\text { to } 2011\end{array}$ \\
\hline Total Assets & 1,910 & 1,910 & 3,313 & 2,536 & 4,015 & 4,861 & 4,348 & $128 \%$ \\
\hline Current Assets & 1,590 & 1,630 & 2,913 & 2,166 & 3,555 & 4,363 & 3,957 & $149 \%$ \\
\hline Total Equity & 1,119 & 1,173 & 1,858 & 1,231 & 1,447 & 1,577 & 1,496 & $34 \%$ \\
\hline Total Revenue & 688 & 591 & 832 & 573 & 566 & 730 & 716 & $4 \%$ \\
\hline Commission Revenue & 366 & 356 & 465 & 366 & 373 & 244 & 433 & $18 \%$ \\
\hline Operating Profit & 226 & 120 & 233 & 19 & 121 & 175 & 188 & $-17 \%$ \\
\hline Net Income & 204 & 131 & 238 & 131 & 205 & 244 & 255 & $25 \%$ \\
\hline
\end{tabular}

Source: The Association of Capital Market Intermediary Institutions of Turkey,

http://www.tspakb.org.tr/index.htm 
Table 3. Descriptives on inputs and outputs

\begin{tabular}{llllll}
\hline Year & N & Labor Mean & Capital Mean & Comission Mean & Other Mean \\
\hline 2005 & 90 & 63.83 & 1530939.43 & 5370085.15 & 4762735.52 \\
2006 & 88 & 65.06 & 1482283.41 & 5732518.02 & 3843202.81 \\
2007 & 92 & 61.03 & 1459513.28 & 6355164.13 & 5314151.07 \\
2008 & 80 & 60.79 & 1614707.86 & 5673555.88 & 4848344.98 \\
2009 & 81 & 57.36 & 1670764.09 & 7021867.73 & 3926696.28 \\
2010 & 84 & 58.24 & 1559827.06 & 8508772.97 & 4110755.81 \\
2011 & 85 & 59.13 & 1325734.68 & 8230009.43 & 5404303.47 \\
\hline
\end{tabular}


Table 4. Descriptives on efficiency scores.

\begin{tabular}{llllll}
\hline Years & $\mathrm{N}$ & Mean & Std. Dev & Min & Max \\
\hline 2005 & 90 & .2025 & .2033 & .034 & 1.000 \\
2006 & 88 & .1809 & .1934 & .028 & 1.000 \\
2007 & 92 & .2458 & .2380 & .029 & 1.000 \\
2008 & 80 & .2483 & .2648 & .010 & 1.000 \\
2009 & 81 & .2433 & .2240 & .023 & 1.000 \\
2010 & 84 & .2311 & .2393 & .016 & 1.000 \\
2011 & 85 & .2668 & .2511 & .010 & 1.000 \\
\hline Bank affiliated & 174 & .3485 & .2598 & .026 & 1.000 \\
Independent & 426 & .1825 & .2004 & .010 & 1.000 \\
\hline Domestic private & 438 & .1714 & .1451 & .010 & 1.000 \\
Foreign & 138 & .4212 & .3444 & .014 & 1.000 \\
Public & 24 & .2178 & .0804 & .091 & .435 \\
\hline Crisis years & 161 & .2458 & .2444 & .010 & 1.000 \\
Other years & 439 & .2252 & .2269 & .013 & 1.000 \\
\hline
\end{tabular}


Table 5. Regression Results

\begin{tabular}{|c|c|c|c|}
\hline \multirow[b]{2}{*}{ Dep. Var: Efficiency } & Model 1 & Model 2 & Model 3 \\
\hline & Fixed effects regression & Random effects regression & Pooled regression \\
\hline \multirow{2}{*}{ Bank affiliated } & $0.950^{* *}$ & $0.906^{* *}$ & $0.584 *$ \\
\hline & $(2.79)$ & $(3.18)$ & $(2.48)$ \\
\hline \multirow{2}{*}{ Domestic state } & 0.0211 & -0.0919 & -0.0678 \\
\hline & $(0.15)$ & $(-1.21)$ & $(-1.33)$ \\
\hline \multirow{2}{*}{ Foreign } & $0.169 * * *$ & $0.203 * * *$ & $0.240 * * *$ \\
\hline & $(4.97)$ & $(6.91)$ & $(8.68)$ \\
\hline \multirow{2}{*}{ LnAssets } & $0.114 * * *$ & $0.0981 * * *$ & $0.0693 * * *$ \\
\hline & $(8.86)$ & $(9.43)$ & $(7.96)$ \\
\hline \multirow[t]{2}{*}{ Polcon } & $0.0991 *$ & $0.0913 *$ & 0.0728 \\
\hline & $(2.33)$ & $(2.28)$ & $(1.34)$ \\
\hline \multirow{2}{*}{ Crisis years } & -0.0234 & -0.0271 & -0.0346 \\
\hline & $(-1.42)$ & $(-1.66)$ & $(-1.46)$ \\
\hline \multirow{2}{*}{ Foreign $\mathrm{x}$ crisis years } & -0.0436 & -0.0404 & -0.0328 \\
\hline & $(-1.54)$ & $(-1.42)$ & $(-0.78)$ \\
\hline \multirow{2}{*}{ Domestic state $\mathrm{x}$ crisis years } & -0.0154 & -0.00815 & -0.0033 \\
\hline & $(-0.25)$ & $(-0.13)$ & $(-0.04)$ \\
\hline \multirow{2}{*}{ Bank affiliated $x$ crisis years } & $0.0965 * * *$ & $0.0943 * *$ & $0.0972 *$ \\
\hline & $(3.38)$ & $(3.29)$ & $(2.29)$ \\
\hline \multirow{2}{*}{ Foreign x Bank affiliation } & $-0.175^{* * *}$ & $-0.133 * *$ & -0.027 \\
\hline & $(-3.34)$ & $(-2.94)$ & $(-0.68)$ \\
\hline \multirow{2}{*}{ Bank affiliation x LnAssets } & $-0.0556 * *$ & $-0.0516 * *$ & $-0.0326^{*}$ \\
\hline & $(-2.77)$ & $(-3.10)$ & $(-2.39)$ \\
\hline \multirow{2}{*}{ Constant } & $-1.742 * * *$ & $-1.475 * * *$ & $-1,015 * * *$ \\
\hline & $(-7.73)$ & $(-8.29)$ & $(-6,75)$ \\
\hline $\mathrm{F}$ & 13.07 & Wald ChiSq $=191.8$ & 28.86 \\
\hline $\mathrm{P}$ & 0.00 & 0.00 & 0.00 \\
\hline Number of groups & 103 & 103 & \\
\hline R-sq: & 0.224 & 0.216 & 0.351 \\
\hline $\mathrm{N}$ & 600 & 600 & 600 \\
\hline Hausman Test & Chi Square $=22.96$ & & \\
\hline $\mathrm{P}$ & 0.01 & & \\
\hline
\end{tabular}


Table 6: Correlation matrix

\begin{tabular}{l|lllllll} 
& Efficiency & $\begin{array}{l}\text { Bank } \\
\text { affiliated }\end{array}$ & $\begin{array}{l}\text { Domestic } \\
\text { state }\end{array}$ & Foreign & LnAssets & $\begin{array}{l}\text { Crisis } \\
\text { years }\end{array}$ & Polcon \\
\hline $\begin{array}{l}\text { Efficiency } \\
\text { Bank } \\
\text { Affiliated }\end{array}$ & 1 & & & & & & \\
$\begin{array}{l}\text { Domestic } \\
\text { state }\end{array}$ &,- 011 &, $319^{* *}$ & 1 & & & & \\
$\begin{array}{l}\text { Foreign } \\
\text { LnAssets }\end{array}$ &, $450^{* *}$ &, $209^{* *}$ &,$- 112^{* *}$ & 1 & & & \\
$\begin{array}{l}\text { Crisis } \\
\text { years }\end{array}$ &, 039 &, $514^{* *}$ &, $170^{* *}$ &, 075 & 1 & & \\
Polcon &,- 047 &, 019 &, 011 &, $089^{* *}$ &, 029 & 1 & \\
\hline
\end{tabular}

**. Correlation is significant at the 0.01 level (2-tailed).

*. Correlation is significant at the 0.05 level (2-tailed). 


\section{References}

AHMED, Z. U., MOHAMAD, O., TAN, B. \& JOHNSON, J. P. 2002. International risk perceptions and mode of entry: a case study of Malaysian multinational firms. Journal of Business Research, 55, 805-813.

AKHIGBE, A. \& MADURA, J. 2004. Bank acquisitions of security firms: the early evidence. Applied Financial Economics, 14, 485-496.

AKTAS, H. \& KARGIN, M. 2007. Efficiency and productivity of brokerage houses in Turkish capital market. Iktisat Isletme ve Finans, 22, 97.

AKYÜZ, Y. \& BORATAV, K. 2003. The Making of the Turkish Financial Crisis. World Development, 31, 1549-1566.

ALTUNBAS, Y., LIU, M.-H., MOLYNEUX, P. \& SETH, R. 2000. Efficiency and risk in Japanese banking. Journal of Banking \& Finance, 24, 1605-1628.

ASSAF, A. G., MATOUSEK, R. \& TSIONAS, E. G. 2013. Turkish bank efficiency: Bayesian estimation with undesirable outputs. Journal of Banking \& Finance, 37, 506-517.

AYSAN, A. F. \& CEYHAN, S. P. 2008. What determines the banking sector performance in globalized financial markets? The case of Turkey. Physica A, 1593-1602.

$\mathrm{BACH}, \mathrm{D}$. 2010. Varieties of cooperation: the domestic institutional roots of global governance. Review of International Studies, 36, 561-589.

BARTHOLDY, J. \& FENG, T. 2013. The quality of securities firms' earnings forecasts and stock recommendations: Do informational advantages, reputation and experience matter in China? Pacific-Basin Finance Journal, 24, 66-88.

BAYYURT, N. \& AKIN, A. 2014. Effects of Foreign Acquisitions on the Performance of Securities Firms: Evidence from Turkey. Procedia - Social and Behavioral Sciences, 150, 156-161.

BELL, G. G. \& ZAHEER, A. 2007. Geography, networks, and knowledge flow. Organization Science, 18, 955-972.

BELL, R. G., FILATOTCHEV, I. \& RASHEED, A. A. 2010. Liability of foreignness: new insights from capital markets. In: DEVINNEY, T., PEDERSEN, T. \& TIHANYI, L. (eds.) The Past, Present and Future of International Business \& Management Emerald Group Publishing Limited.

BENNER, M. J. 2010. Securities Analysts and Incumbent Response to Radical Technological Change: Evidence from Digital Photography and Internet Telephony. Organization Science, 21, 42-62.

BONIN, J. P., HASAN, I. \& WACHTEL, P. 2005. Bank performance, efficiency and ownership in transition countries. Journal of Banking \& Finance, 29, 31-53.

BOONE, T., GANESHAN, R. \& HICKS, R. L. 2008. Learning and Knowledge Depreciation in Professional Services. Management Science, 54, 1231-1236.

BORSA ISTANBUL. 2013. Mission and Vision [Online]. Available: http://borsaistanbul.com/en/corporate/about-borsa-istanbul/mission-and-vision [accessed 29 July 2014].

BROUTHERS, K. D. \& BROUTHERS, L. E. 2002. Institutional, cultural and transaction cost influences on entry mode choice and performance. Journal of International Business, 33, 203-221.

BROUTHERS, K. D. \& BROUTHERS, L. E. 2003. Why service and manufacturing entry mode choices differ: the influence of transaction cost factors, risk and trust. Journal of Management Studies, 40, 1179-1204.

BROUTHERS, K. D., BROUTHERS, L. E. \& WERNER, S. 2003. Transaction cost-enhanced entry mode choices and firm performance. Strategic Management Journal, 24, 1239-1248.

BUCKLEY, P. J., CLEGG, J., CROSS, A. R., LIU, X., VOSS, H. \& ZHENG, P. 2007. The determinants of Chinese outward foreign direct investment. Joumal of International Business Studies, 38, 499-518.

CALHOUN, M. A. 2002. Unpacking liability of foreignness: identifying culturally driven external and internal sources of liability for the foreign subsidiary. Journal of International Management, 8, 301-321. 
CHAN, K., COVRIG, V. \& NG, L. 2005. What Determines the Domestic Bias and Foreign Bias? Evidence from Mutual Fund Equity Allocations Worldwide. The Journal of Finance, 60, 1495-1534.

CHARNES, A., COOPER, W. W. \& RHODES, E. 1978. Measuring the efficiency of decision making units. European Journal of Operational Research, 3, 429-44.

CHEN, H. Y., GRIFFITH, D. A. \& HU, M. Y. 2006. The influence of liability of foreignness on market entry strategies. International Marketing Review, 23, 636-649.

CHEN, S. K., CHEN, X., LIN, B.-X. \& ZHONG, R. 2005. The impact of government regulation and ownership on the performance of securities companies: Evidences from China. Global Finance Journal, 16, 113-124.

CHEN, T. J. 2006. Liability of foreignness and entry mode choice: Taiwanese firms in Europe. Journal of Business Research, 59, 288-294.

CHOI, H. S., CLARKE, J., FERRIS, S. P. \& JAYARAMAN, N. 2009. The effects of regulation on industry structure and trade generation in the US securities industry. Journal of Banking \& Finance, 33, 1434-1445.

CHRISTMANN, P. \& TAYLOR, G. 2006. Firm Self-Regulation through International Certifiable Standards: Determinants of Symbolic versus Substantive Implementation. Journal of International Business Studies, 37, 863-878.

CIHAK, M., DEMIRGUC-KUNT, A., FEYEN, E. \& LEVINE, R. 2012. Benchmarking financial systems around the world. Washington, DC World Bank.

COHEN, W. M. \& LEVINTHAL, D. A. 1990. Absorptive Capacity: A New Perspective on Learning and Innovation. Administrative Science Quarterly, 35, 128-152.

COOPER, W. W., SEIFORD, L. M. \& TONE, K. 2000. Data Envelopment Analysis: A Comprehensive Text with Models, Applications, References and DEA-Solver Software, Boston, Springer.

CUERVO-CAZURRA, A. \& DAU, L. A. 2009. Promarket reforms and firm profitability in developing countries. Academy of Management Journal, 52, 1348-1368.

CUI, L. \& JIANG, F. 2009. FDI entry mode choice of Chinese firms: A strategic behavior perspective. Journal of World Business, 44, 434-444.

DE JONGHE, O., DISLI, M. \& SCHOORS, K. 2012. Corporate Governance, Opaque Bank Activities, and Risk/Return Efficiency: Pre- and Post-Crisis Evidence from Turkey. Journal of Financial Services Research, 41, 51-80.

DELIOS, A. \& HENISZ, W. J. 2003a. Policy uncertainty and the sequence of entry by Japanese firms, 1980-1998. Journal of International Business, 34, 227-241.

DELIOS, A. \& HENISZ, W. J. 2003b. Political Hazards, Experience, And Sequential Entry Strategies: The International Expansion Of Japanese Firms, 1980-1988. Strategic Management Journal, 24, 1153-1163.

DELONG, T. J. \& NANDA, A. 2003. Professional Services: Text and Cases, New York, McGraw/Hill.

DEMIR, N., MAHMUD, S. F. \& BABUSCU, S. 2005. The technical inefficiency effects of Turkish banks after financial liberalization. The Developing Economies, 43, 396-411.

DEMIRBAG, M., MCGUINNESS, M., WOOD, G., \& BAYYURT, N.2015. Context, Law and Reinvestment Decisions: Why the Transitional Periphery Differs from other Post-State Socialist Economies, International Business Review, 2015, 24 (6): 955-965.

DEMIRBAG, M., MCGUINNESS, M. \& ALTAY, H. 2010a. Perceptions of Institutional Environment and Entry Mode: FDI from an Emerging Country Management International Review, 50, 207-240.

DEMIRBAG, M., TATOGLU, E., GLAISTER, K. W. \& ZAIM, S. 2010b. Measuring strategic decision making efficiency in different country contexts: A comparison of British and Turkish firms. Omega, 38, 95-104.

DEMIRBAG, M., TATOGLU, E., \& GLAISTER, K. 2010c. Institutional and transaction cost influence on partnership structure of foreign affiliates, Management International Review, 2010, 50(6): 709-745.

DEMIRBAG, M., TATOGLU, E. \& GLAISTER, K. 2009. Equity-based entry modes of emerging country multinationals: Lessons from Turkey, Journal of World Business, 2009, 44(4):445-462. 
DEMIRBAG, M., GLAISTER, K. \& TATOGLU, E. 2007a. Institutional and transaction cost influences on MNE's ownership strategies of their affiliates: Evidence from an emerging market, Journal of World Business, 2007, 42(4): 418-434.

DEMIRBAG, M.,TATOGLU, E. \& GLAISTER. K. 2007b. Factors influencing perceptions of performance: The case of Western FDI in an emerging market, International Business Review, 2007, 16 (3): 310-336.

DEMIRGUC-KUNT, A., FEYEN, E. \& LEVINE, R. 2011. The evolving importance of banks and securities markets. Washington, DC: World Bank.

DENIZER, C., DINC, M. \& TARIMCILAR, M. 2007. Financial liberalization and banking efficiency: evidence from Turkey. Journal of Productivity Analysis, 27, 177-195.

DOH, J. P., RODRIGUEZ, P., UHLENBRUCK, K., COLLINS, J. \& EDEN, L. 2003. Coping with corruption in foreign markets. Academy of Management Executive, 17, 114-127.

DOMBEY, D. 2013. Turkish bourse chief has a trillion-dollar target. Financial Times, 12 February 2013.

DOMBEY, D. \& BOULTON, L. 2013. Money may be tight, but development will go on. Financial Times, 28 November 2013.

DRAKE, L. \& HOWCROFT, B. 1994. Relative efficiency in the branch network of a UK bank: An empirical study. Omega, 22, 83-90.

DUNNING, J. H. \& LUNDAN, S. 2008. Institutions and the OLI paradigm of the multinational enterprise. Asia Pacific Journal of Management, 25, 573-594.

EDEN, L. 2009. Letter from the Editor-in-Chief: Reverse knowledge transfers, culture clashes and going international. Journal of International Business Studies, 40, 177-180.

ELANGO, B. 2009. Minimizing effects of 'liability of foreignness': Response strategies of foreign firms in the United States. Journal of World Business, 44, 51-62.

ERIKSSON, K. \& CHETTY, S. 2003. The effect of experience and absorptive capacity on foreign market knowledge. International Business Review, 12, 673-695.

FANG, E. \& ZOU, S. 2010. The effects of absorptive and joint learning on the instability of international joint ventures in emerging economies. Joumal of International Business.

FARRELL, M. J. 1957. The Measurement of Productive Efficiency. Journal of the Royal Statistical Society. Series A (General), 120, 253-290.

FERNANDEZ-CASTRO, A. \& SMITH, P. 1994. Towards a general non-parametric model of corporate performance. Omega, 22, 237-249.

FLATTEN, T. C., GREVE, G. I. \& BRETTEL, M. 2011. Absorptive capacity and firm performance in SMEs: The mediating influence of strategic alliances. European Management Review, 8, 137-152.

FUKUYAMA, H. \& MATOUSEK, R. 2011. Efficiency of Turkish banking: Two-stage network system. Variable returns to scale model. Journal of International Financial Markets, Institutions and Money, 21, 75-91.

FUKUYAMA, H. \& WEBER, W. L. 1999. The efficiency and productivity of Japanese securities firms, 1988-93. Japan and the World Economy, 11, 115-133.

GARG, M. \& DELIOS, A. 2007. Survival of the foreign subsidiaries of TMNCs: The influence of business group affiliation. Journal of International Management

Emerging Multinationals from Developing Economies: Motivations, Paths and Performance, 13, 278295.

GOLDBERG, L. G., HANWECK, G. A., KEENAN, M. \& YOUNG, A. 1991. Economies of scale and scope in the securities industry. Journal of Banking \& Finance, 15, 91-107.

GREENLEY, G. E. 1994. Strategic planning and company performance: an appraisal of the empirical evidence. Scandinavian Journal of Management, 10, 383-96.

GREENWOOD, R., DEEPHOUSE, D. L. \& LI, S. X. 2007. Ownership and Performance of Professional Service Firms. Organization Studies, 28, 219-238.

GREENWOOD, R., HININGS, C. R. \& BROWN, J. 1994. Merging Professional Service Firms. Organization Science, 5, 239-257. 
GREENWOOD, R. \& LACHMAN, R. 1996. Change as an Underlying Theme in Professional Service Organizations: An Introduction. Organization Studies, 17, 563-572.

GREENWOOD, R., LI, S. X., PRAKASH, R. \& DEEPHOUSE, D. L. 2005. Reputation, Diversification, and Organizational Explanations of Performance in Professional Service Firms. Organization Science, 16, 661-673.

HAMEL, G. \& PRAHALAD, C. K. 1993. Strategy as stretch and leverage. Harvard Business Review, 71, 76-85.

HENISZ, W. J. 2000. The institutional environment for multinational investment. Journal of Law, Economics and Organization, 16, 334-364.

HENISZ, W. J. 2004. Political Institutions and Policy Volatility. Economics \& Politics, 16, 1-27.

HENISZ, W. J. \& SWAMINATHAN 2008. Introduction to the special issue on Institutions and International Business. Joumal of International Business Studies, 39, 537-539.

HENNART, J.-F., ROEHL, T. \& ZENG, M. 2002. Do exits proxy a liability of foreignness?: The case of Japanese exits from the US. Journal of International Management, 8, 241-264.

HU, J. L. \& FANG, C. Y. 2010. Do market share and efficiency matter for each other? An application of the zero-sum gains data envelopment analysis. Journal of the Operational Research Society, 61, 647-657.

HUGGINS, R. \& WEIR, M. 2012. Intellectual assets and small knowledge-intensive business service firms. Journal of Small Business and Enterprise Development, 19, 92-113.

IHSAN, I. 2007. Bank ownership and productivity developments: evidence from Turkey. Studies in Economics and Finance, 24, 115-139.

ISIK, I. 2008. Productivity, technology and efficiency of de novo banks: A counter evidence from Turkey. Journal of Multinational Financial Management, 18, 427-442.

ISIK, I. \& HASSAN, M. K. 2002. Technical, scale and allocative efficiencies of Turkish banking industry. Journal of Banking \& Finance, 26, 719-766.

ISIK, I. \& HASSAN, M. K. 2003a. Efficiency, Ownership and Market Structure, Corporate Control and Governance in the Turkish Banking Industry. Journal of Business Finance \& Accounting, 30, 1363-1421.

ISIK, I. \& HASSAN, M. K. 2003b. Financial deregulation and total factor productivity change: An empirical study of Turkish commercial banks. Journal of Banking \& Finance, 27, 1455-1485.

JIANG, F. \& STENING, B. W. 2013. Do indigenous firms incur a liability of localness when operating in their home market? The case of China. Journal of World Business, 48, 478-489.

JOHANSON, J. \& VAHLNE, J.-E. 2009. The Uppsala internationalization process model revisited: From liability of foreignness to liability of outsidership. Journal of International Business Studies, 40, 1411-1431.

JOHNSTON, J. \& MADURA, J. 2000. Valuing the Potential Transformation of Banks into Financial Service Conglomerates: Evidence from the Citigroup Merger. The Financial review, 35, 17-36.

KAROLYI, G. A. \& STULZ, R. M. 2003. Are Financial Assets Priced Locally or Globally? In: CONSTANTINIDES, G. M., HARRIS, M. \& STULZ, R. M. (eds.) Handbook of the Economics of Finance. Elsevier.

KOSTOVA, T. \& ZAHEER, S. 1999. Organizational legitimacy under conditions of complexity: The case of the multinational enterprise. Academy of Management Review, 24, 64-81.

KWOK, C. C. Y. \& TADESSE, S. 2006. National culture and financial systems. Journal of International Business Studies, 37, 227-247.

LAUTERBACH, B. \& VANINSKY, A. 1999. Ownership structure and firm performance: Evidence from Israel. Journal of Management and Governance, 3, 189-201.

LEE, D.-G., KIM, J. \& KANG, H. 2014. Do Larger Brokerage Firms Enjoy Larger Economies of Scale and Scope? Seoul Journal of Economics, 27, 445-467.

LEVINE, R. \& ZERVOS, S. 1998. Stock Markets, Banks, and Economic Growth. The American Economic Review, 88, 537-558. 
LIAO, C.-S. \& YANG, C.-H. 2010. Efficiency, Productivity and Ownership Structure for Securities Firms in Taiwan. Journal of Money, Investment and Banking.

LIU, S. 2008. Commission deregulation and performance of securities firms: Further evidence from Japan. Journal of Economics and Business, 60, 355-368.

LOWENDAHL, B. R. 2000. Strategic Management of Professional Service Firms, Copenhagen Business School Press.

LUO, Y., SHENKAR, O. \& NYAW, M.-K. 2002. Mitigating liabilities of foreignness: Defensive versus offensive approaches. Journal of International Management, 8, 283-300.

MACPHERSON, A. \& HOLT, R. 2007. Knowledge, learning and small firm growth: A systematic review of the evidence. Research Policy, 36, 172-192.

MARABELLI, M. \& NEWELL, S. 2014. Knowing, Power and Materiality: A Critical Review and Reconceptualization of Absorptive Capacity. International Journal of Management Reviews, 16, 479-499.

MEYER, J. W. \& ROWAN, B. 1977. Institutionalized Organizations: Formal Structure as Myth and Ceremony. The American Journal of Sociology, 83, 340-363.

MEYER, K. E., MUDAMBI, R. \& NARULA, R. 2011. Multinational Enterprises and Local Contexts: The Opportunities and Challenges of Multiple Embeddedness. Journal of Management Studies, 48, 235-252.

MEYER, K. E. \& PENG, M. 2016. Theoretical Foundations of Emerging Economy Business Research. Journal of International Business Studies.

MEZIAS, S. J., CHEN, Y.-R., MURPHY, P., BIAGGIO, A., CHUAWANLEE, W., HUI, H., OKUMURA, T. \& STARR, S. 2002. National cultural distance as liability of foreignness: the issue of level of analysis. Journal of International Management, 8, 407-421.

MILLAR, C. \& CHOI, C. J. 2009. Reverse knowledge and technology transfer: imbalances caused by cognitive barriers in asymmetric relationships. International Journal of Technology Management, 48, 389-402.

MILLER, K. D. 1992. A framework for integrated risk management in international business. Journal of International Business Studies, 23, 311-331.

MILLER, K. D. 1993. Industry and country effects on managers' perceptions of environmental uncertainties. Journal of International Business Studies, 24, 693-714.

NACHUM, L. 2003. Liability of foreignness in global competition? Financial service affiliates in the City of London. Strategic Management Journal, 24, 1187-1208.

NACHUM, L. 2010. When Is Foreignness an Asset or a Liability? Explaining the Performance Differential Between Foreign and Local Firms. Journal of Management, 36, 714-739.

NACHUM, L. \& ZAHEER, S. 2005. The persistence of distance? The impact of technology on MNE motivations for foreign investment. Strategic Management Journal, 26, 747-767.

NORTH, D. C. 1990. Institutions, Institutional Change And Economic Performance, Cambridge, Cambridge University Press.

ÖNIS, Z. \& BAKıR, C. 2007. Turkey's Political Economy in the Age of Financial Globalization: The Significance of the EU Anchor. South European Society \& Politics, 12, 147-164.

PATTERSON, W. \& AMBROSINI, V. 2015. Configuring absorptive capacity as a key process for research intensive firms. Technovation, 36, 77-89.

PEREZ-BATRES, L. A. 2012. Efficient labor reallocation and the liability of localness : unintended consequences of NAFTA and other commercial agreements. American Journal of Business 27, 79-90.

PEREZ-BATRES, L. A. \& EDEN, L. 2008. Is there a liability of localness? How emerging market firms respond to regulatory punctuations. Journal of International Management

Institutional Changes and Organizational Transformation in Developing Economies, 14, 232-251.

PÉREZ-NORDTVEDT, L., BABAKUS, E. \& KEDIA, B. L. 2010. Learning from international business affiliates: developing resource-based learning capacity through networks and knowledge acquisition. Journal of International Management, 16, 262-274. 
PETERSEN, B. \& PEDERSEN, T. 2002. Coping with liability of foreignness: Different learning engagements of entrant firms. Journal of International Management, 8, 339-350.

PORTES, R. \& REY, H. 2005. The determinants of cross-border equity flows. Journal of International Economics, 65, 269-296.

PORTES, R., REY, H. \& OH, Y. 2001. Information and capital flows: The determinants of transactions in financial assets. European Economic Review, 45, 783-796.

QUER, D., CLAVER, E. \& RIENDA, L. 2011. Political risk, cultural distance, and outward foreign direct investment: Empirical evidence from large Chinese firms. Asia Pacific Journal of Management, forthcoming.

RADIĆ, N., FIORDELISI, F. \& GIRARDONE, C. 2012. Efficiency and Risk-Taking in Pre-Crisis Investment Banks. Journal of Financial Services Research, 41, 81-101.

RANGAN, S. \& DRUMMOND, A. 2004. Explaining outcomes in competition among foreign multinationals in a focal host market. Strategic Management Journal, 25, 285-93.

RODRIGUEZ, P., SIEGEL, D. S., HILLMAN, A. \& EDEN, L. 2006. Three lenses on the multinational enterprise: politics, corruption, and corporate social responsibility. Journal of International Business Studies, 37, 733-746.

RODRIGUEZ, P., UHLENBRUCK, K. \& EDEN, L. 2005. Government corruption and the entry strategies of multinationals. Academy of Management Review, 30, 383-396.

RODRIK, D. 1990. Premature Liberalization, Incomplete Stabilization: the Ozal Decade in Turkey. NBER Working Papers. National Bureau of Economic Research, Cambridge, M.A.

SCOTT, W. R. 2008a. Institutions and Organizations, Sage.

SCOTT, W. R. 2008b. Lords of the Dance: Professionals as Institutional Agents. Journal of Management Studies, 29, 219-238.

SEIFORD, L. M. 1996. Data envelopment analysis: The evolution of the state of the art (1978-1995). Journal of Productivity Analysis, 7, 99-137.

SEIFORD, L. M. \& ZHU, J. 1999. Profitability and Marketability of the Top 55 U.S. Commercial Banks. Management Science, 45, 1270-1288.

SETHI, D. \& GUISINGER, S. 2002. Liability of foreignness to competitive advantage: How multinational enterprises cope with the international business environment. Journal of International Management, 8, 223-240.

SETHI, D. \& JUDGE, W. 2009. Reappraising liabilities of foreignness within an integrated perspective of the costs and benefits of doing business abroad. International Business Review, 18, 404416.

SHARMA, A. 1997. Professional as agent: knowledge asymmetry in agency exchange. Academy of Management Review, 22, 758-798.

SHRADER, C. B., TAYLOR, L. \& DALTON, D. R. 1984. Strategic planning and organizational performance: a critical appraisal. Journal of Management, 10, 149-71.

SIMONIN, B. L. 2004. An empirical investigation of the process of knowledge transfer in international strategic alliances. Journal of International Business Studies, 35, 407-427.

SONG, K. R., MANTECON, T. \& ALTINTIG, Z. A. 2012. Chaebol-affiliated analysts: Conflicts of interest and market responses. Journal of Banking \& Finance, 36, 584-596.

SÖNMEZ, Ü. 2011. The Political Economy of Market and Regulatory Reforms in Turkey: The Logic and Unintended Consequences of Ad-hoc Strategies. New Political Economy, 16, 101 - 130.

STARBUCK, W. H. 1992. Learning by knowledge-intensive firms. Journal of Management Studies, 29, 713-740.

TEECE, D. J. 2003. Expert talent and the design of (professional services) firms. Industrial and Corporate Change, 12, 895-916.

TURHAN, I. 2014. Chairman's letter. Borsa Istanbul Magazine. Borsa Istanbul.

UHLENBRUCK, K., RODRIGUEZ, P., DOH, J. \& EDEN, L. 2006. The impact of corruption on entry strategy: Evidence from telecommunication projects in emerging economies. Organization Science, 17, 402-414. 
VAHLNE, J. E., SCHWEIZER, R. \& JOHANSON, J. 2012. Overcoming the Liability of Outsidership-The Challenge of HQ of the Global Firm. Journal of International Management, 18, 224-232.

VON NORDENFLYCHT, A. 2010. What is a professional service firm? Toward a theory and taxonomy of knowledge-intensive firms. Academy of Management Review, 35, 155-174.

WALTER, I. 2009. Economic Drivers of Structural Change in the Global Financial Services Industry. Long Range Planning, 42, 588-613.

WANG, K., HUANG, W., WU, J. \& LIU, Y.-N. 2014. Efficiency measures of the Chinese commercial banking system using an additive two-stage DEA. Omega, 44, 5-20.

WERNER, S., BROUTHERS, L. E. \& BROUTHERS, K. D. 1996. International risk and perceived environmental uncertainty: the dimensionality and internal consistency of Miller's measure. Journal of International Business Studies, 28, 571-587.

WHALEN, G. 1999. Trends in Organizational Form and their Relationship to Performance: The Case of Foreign Securities Subsidiaries of U.S. Banking Organizations. Journal of Financial Services Research, 16, 181-218.

WILLIAMS, J. W. 2009. Envisioning financial disorder: financial surveillance and the securities industry. Economy and Society, 38, 460-491.

WOOD, G. \& DEMIRBAG, M. 2012. (Eds.) Handbook of Institutional Approaches to International Business, Chelthenham, Edward Elgar.

YORGANCIOGLU, S. 2010. Turkey is a tempting target for private equity investors. The Financial Times, January 282010.

ZAHEER, S. 1995. Overcoming the liability of foreignness. Academy of Management Journal, 38, 341363.

ZAHEER, S. 2002. The liability of foreignness, redux: a commentary. Journal of International Management, 8, 351-358.

ZAHEER, S. \& MOSAKOWSKI, E. 1997. The Dynamics of the Liability of Foreignness: A Global Study of Survival in Financial Services. Strategic Management Journal, 18, 439-463.

ZAHRA, S. A. \& GEORGE, G. 2002. Absorptive Capacity: A Review, Reconceptualization, and Extension. The Academy of Management Review, 27, 185-203.

ZAIM, O. 1995. The effect of financial liberalization on the efficiency of Turkish commercial banks. Applied Financial Economics, 5, 257-264.

ZHANG, W. D., ZHANG, S. \& LUO, X. 2006. Technological progress, inefficiency, and productivity growth in the US securities industry, 1980-2000. Journal of Business Research, 59, 589-594. 